\title{
POEMAS
}

\section{Helena Kolody}

\section{J A R D I M}

Cultivo um jardim.

Apanho um punhado

de escuras sementes

no vocabulário

e espalho nos sulcos

que o sonho acordado

arou na emoção.

Se a palavra é exata, põe-se a germinar, brotam-lhe raizes, cresce em permanência, como coisa viva.

\section{AQUARELA ESLAVO - BRASILEIRA}

Na memória do sangue, há bosques de bétulas, estepes de urzes floridas, "colomêicas" e trenós.

Arde o trópico nos nervos.

Crepita a alegria da pátria jovem.

A alma se aquece na chama das côres.

Dança o coração em ritmo sincopado. 


\section{MATERIALISTA}

Edificou a existência

bem circundada de muros.

Por que pressente no ser

um perpassar de infinito?

Donde lhe chega um perfume

como de searas maduras

numa terra prometida?

\section{PÂNICO}

Não há mais lugar no mundo.

Não há mais lugar.

Com o número, crescem a insegurança e o mêdo.

De repente, a vida tornou-se estreita:

um desfiladeiro

por onde os homens se precipitam em pânico, a fugir sem saber de quê.

\section{INDIGËNCIA}

Dói-me a indigência do próximo, sua exígua morada nos dias, - afã de construir na areia, com mãos de vento, castelos de circunstância sem mirantes para o mar. 


\section{SÁBIOS}

Sismos sacodem o mundo.

Lavra o incêndio dos conflitos.

No centro do furacão,

absortos,

os sábios meditam.

$E$ anotam profundas reflexões

em pequenas laudas de papel.

\section{INTERCORRENCIA}

Entre o gesto e a sombra,

há luz e distância

e uma geometria

de ângulos e planos.

\section{COMPLEXIDADE}

Eu não sou o que penso que sou

nem o que os outros julgam que eu seja.

Há Atlântidas submersas

nos abismos insondáveis do ser. 